Original Research

\title{
Effects of Depth and Land Cover on Soil Properties as Indicated by Carbon and Nitrogen-Stable Isotope Analysis
}

\author{
Fathia Alaswad ${ }^{1,2}$, Ferdaus Mohamat-Yusuff ${ }^{1 *}$, Khairiah $\mathbf{J .}^{3}$, \\ Faradiella Mohd. Kusin ${ }^{1}$, Roslan Ismail ${ }^{4}$, Zulfa Hanan Asha-ari ${ }^{1}$ \\ ${ }^{1}$ Department of Environmental Science, Faculty of Environmental Studies, Universiti Putra Malaysia, \\ 43400 Serdang \\ ${ }^{2}$ Higher Institute for Comprehensive Careers, Gheryan, Libya \\ ${ }^{3}$ Environmental and Natural Resources, Faculty of Science and Technology, National University Malaysia, \\ 43600 Bangi, Selangor \\ ${ }^{4}$ Department of Land Management, Faculty of Agriculture, Universiti Putra Malaysia, \\ 43400 UPM Serdang
}

Received: 5 February 2017

Accepted: 26 May 2017

\begin{abstract}
The aim of this study was to evaluate the effect of soil depths $(0-30,30-60$, and 60-90 cm) and landcover changes on selected physicochemical properties in soils transformed from a secondary forest status to plantation status for the cultivation of rubber and oil palm aged 5 and 15 years. Soil physicochemical properties; bulk density $(\mathrm{Bd}), \mathrm{pH}$, soil organic matter (SOM), total organic carbon (TOC), total organic nitrogen (TON), and their corresponding isotopes; and $\delta^{13} \mathrm{C}$ and $\delta^{15} \mathrm{~N}$ were determined by conventional methods. The results showed that the content of SOM (3.39\%) at 0-30 cm was significantly greater than those of the 30-60 and 60-90 cm depths. The same pattern was demonstrated by the content of TOC and TON. With respect to land use, the secondary forest had significantly greater SOM content than the rubber and oil palm plantations aged 5 years. The same pattern was also observed for the content of TOC and TON by land use. Similarly, the $\delta^{13} \mathrm{C}$ value of $-26.85 \%$ was greatest at the $0-30 \mathrm{~cm}$ depth, while by land use the oil palm aged 5 years had the greatest $\delta^{13} \mathrm{C}$. Conversely, the $\delta^{15} \mathrm{~N}$ value of $4.21 \%$ was significantly greater at the $60-90 \mathrm{~cm}$ depth compared to the $30-60(1.78 \%)$ and the $0-30 \mathrm{~cm}(-2.03 \%)$ depths. The negative value of $\delta^{15} \mathrm{~N}$ revealed the sources ( $\mathrm{N}$ was a product of multiple variables such as $\mathrm{N}$ fixation, precipitation, rainstorm, and the use of chemical fertilizers), and the limited nitrogen content in the study area. In conclusion, this study demonstrated that the conversion of secondary forest to plantation enhanced the mineralization of soil
\end{abstract}

*e-mail: ferdius@upm.edu.my 
organic matter and increased SOC concentrations at the sub soil. Therefore, the conversion of the secondary forest to the oil palm plantations must have resulted in a positive effect by contributing to greater soil organic carbon content.

Keywords: $\quad \delta^{13} \mathrm{C}$ and $\delta^{15} \mathrm{~N}$ stable isotopes, carbon cycle, land use, agricultural soils, soil depth

\section{Introduction}

Soil organic matter (SOM) is known to be an important factor in C-driven climate change [1-2]. Several investigators are presently paying attention to studies relating to SOM dynamics and the capacity of soils to accumulate and give stability to organic carbon following conversion to different land use changes [35]. It has also been pointed out that land use changes can impact the soil $\mathrm{C}$ cycle [6-7] through biomass removal and decomposition of soil organic carbon (SOC) [8]. It is estimated that the transformation of natural ecosystems to regulated ecosystems accounts for $12-15 \%$ of $\mathrm{CO}_{2}$ emissions worldwide [8-9].

In particular, agricultural soils are generally considered to be sources of greenhouse gases, and their proper management can result in the soil serving as a sink of $\mathrm{CO}_{2}[2,8,10-12]$. In contrast, others reported a net gain of carbon [13-15]. Recent studies on SOC storage and turnover have employed the evaluation of ${ }^{13} \mathrm{C}$ and ${ }^{15} \mathrm{~N}$ natural abundances as a technique to determine changes in $\mathrm{C}$ and $\mathrm{N}$ dynamics in relation to land use/land cover changes [16-18]. For instance, stable $\mathrm{C}$ and $\mathrm{N}$ isotopes have been previously employed to gain knowledge of the mechanisms of plant litter decay, SOM evolution, and turnover [19-21], to understand the sources of organic carbon [19-22], the origins of soil $\mathrm{N}$ among different ecosystems or soil disturbances as a result of change in land use [18, 23-24], and nitrogen cycling and mineralization [25-26]. It is noteworthy that all the studies mentioned above are related to the topsoil. However, the influence of soil depth on soil $\mathrm{C}$ dynamics as affected by land use changes still remain poorly understood. In particular, deep soils are a major reservoir of organic $\mathrm{C}$ in terrestrial ecosystems, and it is generally accepted that they are known to store more than half of the total soil C [27]. Therefore, a small change in deep soil $\mathrm{C}$ can have a major effect on overall soil C dynamics [28]. Consequently, a thorough understanding of how much SOC mineralization is sensitive to fresh organic $\mathrm{C}$ input in relation to land use changes will be useful in understanding the responses of the soil C pools to global climatic changes [29]. This is because SOC mainly originates from terrestrial higher plant remnants, hence the fractionation of SOC decomposition in soil is lower than that of $\mathrm{CO}_{2}$ fixation by plants during photosynthesis [20], and the $\delta^{13} \mathrm{C}$ of SOC is more or less the same with those of the plant from where it was derived.

Therefore, the objectives of this study were to determine the effects of soil depth and land cover on the soil physicochemical properties, namely: bulk density $(\mathrm{Bd}), \mathrm{pH}$, soil organic matter (SOM), total organic carbon
(TOC), total organic nitrogen (TON), and to understand the responses of soil $\delta^{13} \mathrm{C}$ and $\delta^{15} \mathrm{~N}$ to land use changes and different soil depths.

\section{Materials and Methods}

\section{Site Description}

This study was conducted in the Ayer Hitam forest reserves in Puchong, Malaysia $\left(3^{\circ} 00^{\prime} 51^{\prime \prime} \mathrm{N}\right.$ and $101^{\circ} 38^{\prime} 17^{\prime \prime E}$ ), and an agricultural plantation of oil palm aged 5 and 15 years, as well as a 15-year-old rubber plantation at University Putra Malaysia (UPM), Serdang, Selangor $\left(002^{\circ} 58^{\prime} 57.65^{\prime \prime} \mathrm{N}\right.$ and $101^{\circ} 43^{\prime} 32.14 " \mathrm{E}$; Fig. 1). The study area is characterized by a tropical climate with a mean annual temperature of $38^{\circ} \mathrm{C}$ and a mean annual precipitation of 2,000 $\mathrm{mm}$. The soil in the Ayer Hitam forest is classified as the Munchong Series, while the classification of the Malacca Series at the UPM plantation was based on [30-31], respectively. An experimental plot of $50 \times 50 \mathrm{~m}$ with three replicates was designed for the field experiment. All three land use types have the same soil type and similar physiographic characteristics and slope gradients.

\section{Soil Sampling and Analysis}

In March 2015 soils were sampled using a steel ring soil sampler. The depth intervals sampled were $0-30,30-$ 60 , and $60-90 \mathrm{~cm}$ at all sites. In the oil palm plantation sites, samples were collected from the different distances at the oil palm plantations, namely: $1.5 \mathrm{~m}$ for the weeded circle, 3 $\mathrm{m}$ for inter raw, and $4.5 \mathrm{~m}$ for the frond heap, away from the oil palm base. Later they were subsequently homogenized into one sample and dried prior to their analysis. For each depth interval, soil texture was determined using the pipette method [32], organic matter (OM) was by loss on ignition method [33], carbon and nitrogen contents were analyzed by combustion [3], and the $\delta^{13} \mathrm{C}$ and $\delta^{15} \mathrm{~N}$ stable isotopes were determined according to the methods modified by [34]. The identification of $\delta^{13} \mathrm{C}$ and $\delta^{15} \mathrm{~N}$ stable isotopes and $\mathrm{C}$ and $\mathrm{N}$ content were done using an elemental analyzer connected online to continuous flow isotope ratio mass spectrometry (CF-IRMS) at the Stable Isotope Laboratory (Nuclear Malaysia). Isotopic ratios are expressed in conventional delta $(\delta)$ notation in parts per thousand:

$$
\delta(\%)=\left\{\frac{\mathrm{R} \text { sample }-\mathrm{R} \text { standard }}{\mathrm{R} \text { standard }}\right\} \times 1000
$$




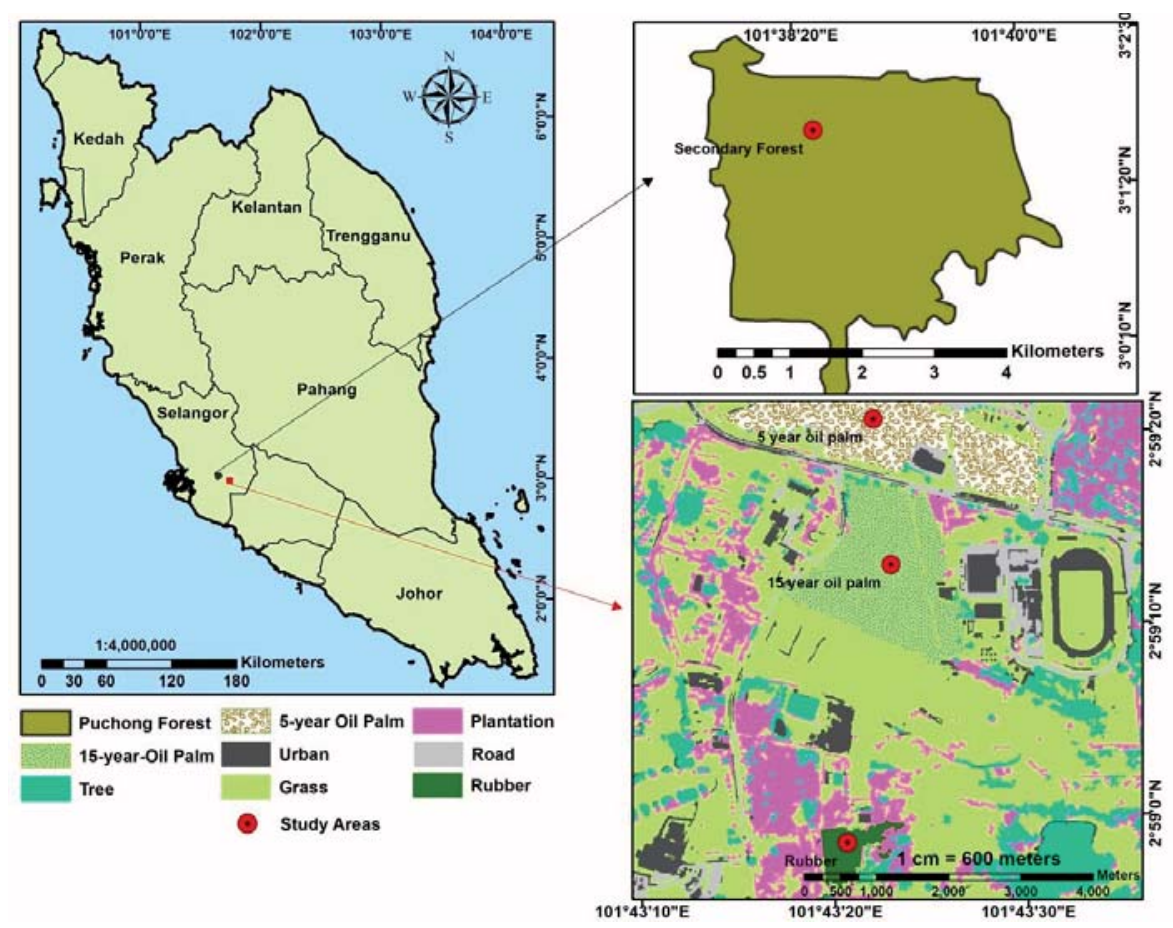

Fig. 1. The study area: The secondary forest and plantation area in Universiti Putra Malaysia (UPM) at Selangor State (Malaysia) are shown.

Where $\mathrm{R}$ represents the molar ratios of the heavy to that of the light isotope: ${ }^{13} \mathrm{C} /{ }^{12} \mathrm{C}$ and ${ }^{15} \mathrm{~N} /{ }^{14} \mathrm{~N}$ of the sample. The international standard is V-PDB (Vienna Pee Dee Belemnite) for $\delta^{13} \mathrm{C}$ and atmospheric $\mathrm{N}_{2}$ reference for $\delta^{15} \mathrm{~N}$ and the precision of triplicate measurements was $0.1 \%$ for $\delta^{13} \mathrm{C}$ and $0.2 \%$ for $\delta^{15} \mathrm{~N}$.

\section{Statistical Analysis}

Statistical analysis was conducted using the statistical package, SPSS software version 21 (SPSS Inc., Chicago, USA). A two-way analysis of variance (ANOVA) was conducted to evaluate the variation in total carbon and nitrogen and $\delta^{13} \mathrm{C}$ and $\delta^{15} \mathrm{~N}$ stored at the different land cover and between depths. Subsequently, Tukey's b test was applied for the multiple comparison. Statistically significant differences were tested at $\mathrm{p} \leq 0.05$. Pearson's correlation coefficient was also calculated to test the correlations between the chemical properties $(\mathrm{pH}$ and $\mathrm{SOM}$ ) of soil and $\delta^{15} \mathrm{~N}$ stable isotopes in different land covers.

\section{Results and Discussion}

\section{Effect of Soil Depth and Land Cover on Physiochemical Properties}

\section{Bulk Density (Bd)}

The results of the effect of soil depth and land use on the bulk density of the secondary forest, rubber, and oil palm plantation aged 5 and 15 years are summarized in Table 1. As shown in Table 1, the deepest part of the subsoil at the secondary forest and oil palm plantation aged 15 years had significantly greater bulk densities than the surface soil 0-30 cm depth. Conversely, the effect of soil depth on the bulk densities of the rubber and oil palm plantation aged 5 years were similar for all the depths. The $60-90 \mathrm{~cm}$ depth had the highest $\mathrm{Bd}$, which varies with soil depths. This depth $(60-90 \mathrm{~cm})$ is known to contain higher clay content. Consequently, there was an increase in the percentage of clay content with the increase in depth of the subsoil horizon, and the same result was reported by [35]. This study suggested that greater clay content with depth is the most likely reason for the higher Bd in the subsoil.

Regarding the effects of land cover on bulk density, oil palm aged 5 years and rubber plantations represented significantly greater bulk densities relative to those of the secondary forest and oil palm plantation aged 15 years at the top soil $(0-30 \mathrm{~cm})$. On the other hand, land cover did not show any effect on bulk density in the soil below $30 \mathrm{~cm}$. This is consistent with the results of the study conducted by [36-37]. Further, studies have demonstrated that the loss of organic matter through the conversion of forest to plantation results in higher Bd values [38]. In addition, the high $\mathrm{Bd}$ values are an indicator of soil compaction in plantations [39].

\section{$\mathrm{pH}$}

The results of the effect of soil depths on the $\mathrm{pH}$ of the secondary forest, rubber, and oil palm plantations 
Table 1. Comparison of Bulk density (Bd), pH, soil organic matter (SOM), total organic carbon (TOC), and total organic nitrogen (TON) between secondary forest, rubber, and oil palm plantations aged 5 and 15 years based on depths and land use.

\begin{tabular}{|c|c|c|c|c|c|c|}
\hline \multirow{4}{*}{ Location } & \multicolumn{6}{|c|}{ Treatment } \\
\hline & \multicolumn{6}{|c|}{ Depth (cm) } \\
\hline & \multicolumn{3}{|c|}{$\mathrm{Bd}\left(\mathrm{g} / \mathrm{cm}^{3}\right)$} & \multicolumn{3}{|c|}{$\mathrm{pH}$} \\
\hline & $0-30$ & $30-60$ & $60-90$ & $0-30$ & $30-60$ & $60-90$ \\
\hline $\mathrm{SF}$ & $0.79 \pm 0.09$ a. A & $1.52 \pm 0.003 \mathrm{~b}$ & $1.6 \pm 0.06 \mathrm{~b}$ & $3.13 \pm 0.03$ a. A & $4.33 \pm 0.13$ b. B & $4.72 \pm 0.11$ b. B \\
\hline $\mathrm{R}$ & $1.45 \pm 0.10$ b. B & $1.64 \pm 0.06 \mathrm{~b}$ & $1.74 \pm 0.03 \mathrm{~b}$ & $3.85 \pm 0.12$ a. $\mathrm{AB}$ & $4.58 \pm 0.15$ b. B & $4.83 \pm 0.12$ b. B \\
\hline OP5 & $1.35 \pm 0.16$ b. B & $1.56 \pm 0.014 \mathrm{~b}$ & $1.63 \pm 0.04 \mathrm{~b}$ & $3.96 \pm 0.18$ a. B & $4.58 \pm 0.01 \mathrm{ab} . \mathrm{B}$ & $4.65 \pm 0.14$ b. B \\
\hline \multirow[t]{2}{*}{ OP15 } & $1.20 \pm 0.12$ a. AB & $1.57 \pm 0.02 \mathrm{ab}$ & $1.69 \pm 0.04 \mathrm{~b}$ & $3.40 \pm 0.25$ a. A & $4.76 \pm 0.03$ b. B & $5.06 \pm 0.27$ b. B \\
\hline & \multicolumn{3}{|c|}{ SOM (\%) } & \multicolumn{3}{|c|}{ TOC (\%) } \\
\hline SF & $3.39 \pm 0.06$ a. A & $2.56 \pm 0.29 \mathrm{~b}$ & $1.68 \pm 0.15 \mathrm{c}$ & $1.97 \pm 0.04$ a. A & $1.48 \pm 0.17 \mathrm{~b}$ & $0.97 \pm 0.09$ c. C \\
\hline $\mathrm{R}$ & $2.25 \pm 0.02$ a. B & $1.55 \pm 0.10 \mathrm{~b}$ & $1.52 \pm 0.01 \mathrm{~b}$ & $1.30 \pm 0.01$ a. B & $0.90 \pm 0.06 \mathrm{~b}$ & $0.88 \pm 0.01$ b. B \\
\hline OP5 & $3.21 \pm 0.22 \mathrm{a} . \mathrm{B}$ & $2.31 \pm 0.72 \mathrm{ab}$ & $1.60 \pm 0.20 \mathrm{~b}$ & $1.32 \pm 0.16$ a. B & $0.88 \pm 0.03 \mathrm{~b}$ & $0.78 \pm 0.06$ b. B \\
\hline \multirow[t]{2}{*}{ Op15 } & $2.29 \pm 0.28$ a. A & $1.52 \pm 0.04 \mathrm{~b}$ & $1.35 \pm 0.10 \mathrm{~b}$ & $1.86 \pm 0.13$ a. $\mathrm{A}$ & $1.34 \pm 0.41 \mathrm{ab}$ & $0.92 \pm 0.12$ b. B \\
\hline & \multicolumn{3}{|c|}{ TON (\%) } & \multicolumn{3}{|c|}{$\mathrm{C} / \mathrm{N}$ ratio } \\
\hline SF & $0.18 \pm 0.03$ a. A & $0.14 \pm 0.01$ a. A & $0.10 \pm 0.01$ a. A & $11.01 \pm 1.52$ & $10.77 \pm 0.69$ & $9.83 \pm 1.52$ \\
\hline $\mathrm{R}$ & $0.09 \pm 0.01$ a. B & $0.06 \pm 0.01$ b. B & $0.06 \pm 0.01$ b. B & $13.52 \pm 1.25$ & $14.25 \pm 0.48$ & $15.05 \pm 1.45$ \\
\hline OP5 & $0.14 \pm 0.01 \mathrm{a} . \mathrm{AB}$ & $0.08 \pm 0.01$ b. B & $0.07 \pm 0.01$ b. B & $12.04 \pm 0.16$ & $15.61 \pm 4.07$ & $13.84 \pm 1.85$ \\
\hline OP15 & $0.11 \pm 0.02$ a. $\mathrm{AB}$ & $0.08 \pm 0.01$ a. B & $0.01 \pm 0.01 \mathrm{a} . \mathrm{AB}$ & $12.20 \pm 0.91$ & $11.34 \pm 1.07$ & $11.42 \pm 0.58$ \\
\hline
\end{tabular}

$* \mathrm{SF}=$ secondary forest, $\mathrm{R}=$ rubber, $\mathrm{OP} 5=$ oil palm 5 years, $\mathrm{OP} 15=$ oil palm 15 years

*Values are means \pm SE. Means followed by small letter (a-c) are significantly different for each parameters in raw (among depth); meanwhile, A-C means are significantly different for each parameter in columns (among land use) using least significant differences (LSD); $\mathrm{p} \leq 0.05$. No letter following indicates no significant differences.

aged 5 and 15 years are summarized in Table 1 . As shown in Table 1, the deepest part of the soil, i.e., the subsoil $60-90 \mathrm{~cm}$ and the $(30-60 \mathrm{~cm})$ depths, had significantly higher $\mathrm{pH}$ value than the surface soil $0-30 \mathrm{~cm}$ depth.

With regards to the effect of land cover on $\mathrm{pH}$, the oil palm plantation aged 5 years had a significantly higher $\mathrm{pH}$ value at $0-30 \mathrm{~cm}$, relative to those of the rubber, aged 15 years, and the secondary forest. Conversely, soil $\mathrm{pH}$ was similar for all the locations at the 30-60 and 60-90 cm depths.

The 60-90 $\mathrm{cm}$ depth had the highest $\mathrm{pH}$ value, while the oil palm aged 15 years had the highest $\mathrm{pH}$ based on location. In general, the acidic $\mathrm{pH}$ values of the soils may be due to the nature of the parent soil materials and the high rainfall ( $\geq 2000 \mathrm{~mm}$ ), which increases the $\mathrm{H}^{+}$activity in soils as the water molecule dissociates [40-41], and in turn results in intense leaching of the basic cations through the soil profiles. As a result, the higher $\mathrm{pH}$ demonstrated by the $60-90 \mathrm{~cm}$ depth may be due to the accumulation of basic cations at this depth, which partially neutralizes the acid soils. The $\mathrm{pH}$ values in the investigated sites were consistent with the $\mathrm{pH}$ values demonstrated by the tropical soil [13]. Conversely, the significant differences demonstrated between the $\mathrm{pH}$ value of the secondary forest and those of the plantations may be most likely due to liming practice within the plantations [42] and to the phosphate fertilizer application [43-45].

\section{Soil Organic Matter (SOM)}

The results of the effect of soil depths on the SOM at the investigated site are summarized in Table 1. As seen in Table 1, the topsoil, i.e., the 0-30 cm depth, had significantly greater SOM content than those of the subsoil $30-60$ and $60-90 \mathrm{~cm}$ depths. The effect of soil depth on SOM on the rubber, aged 5 and 15 years, followed the same pattern with that of the secondary forest.

Considering the effect of land cover on SOM content, secondary forest and the oil palm aged 15 years had a significantly greater SOM content than rubber and oil palm aged 5 years at the $0-30 \mathrm{~cm}$ depth. Conversely, no differences in the SOM were observed between locations at the $30-60 \mathrm{~cm}$ and the $60-90 \mathrm{~cm}$ depths.

The $0-30 \mathrm{~cm}$ depth had the highest SOM between depths, while between land cover, the secondary forest had the highest SOM. The greater SOM content exhibited by the topsoil in this study is also consistent with that demonstrated in the study by [44]. The variation in the SOM content between the different depths of secondary forest and plantation sites may be due to the mixing and 
management processes executed during forest clearance [41], and the intense use of cultivation facilities, which causes an increase in the decomposition rate of SOM and microbial activity [46].

\section{Total Organic Carbon (TOC)}

As shown in Table 1, the topsoil, i.e., the 0-30 cm depth, had significantly greater TOC content than those of the 30-60 and 60-90 cm depths at all investigated sites.

Regarding the effect of land cover on the TOC, both in the secondary forest and the oil palm plantations aged 15 years at the $0-30 \mathrm{~cm}$ depth had significantly greater TOC content than those of the rubber and oil palm aged 5 years.

There was a high amount of TOC within the 0-30 $\mathrm{cm}$ depth, and the highest amount of TOC content was identified within the secondary forest among the locations. Similar TOC percentage values were also demonstrated in the study by [47]. In general, the TOC decreased with soil depth. In terms of the locations, there were no differences in the TOC content of secondary forest and that of the oil palm aged 15 years within the 0-30 and 30-60 cm depths. This is consistent with the results of the study by [48-49], who reported that the SOC content increased over time under oil palm plantation. Furthermore, lack of differences between secondary forest and oil palm plantation aged 15 years had also been demonstrated by other investigators $[15,50]$. When the rubber and oil palm aged 5 years were compared, a similar lack of differences in TOC were also demonstrated in the study by [51]. A possible reason for the lack of difference in TOC may be a result of the lack of significant difference in the SOM content observed within the same soil depth, minimum soil tillage, and maximum residue incorporation [13]. In addition, soil $\mathrm{pH}$ is reported to influence decomposition rates of SOC [52]. This study suggested that the reason why the secondary forest has significantly higher TOC content than the rubber and oil palm plantation aged 5 years may be due to the differences in $\mathrm{pH}$ values between the locations. The lower TOC content exhibited by the subsoil was also reported by $[15$, 53]. However, it may be possible that the minimum loss of TOC content after conversion of the secondary forest to plantation may be attributable to the high clay content found in the study area. Moreover, clay was reported to have reduced $\mathrm{C}$ losses due to forest conversion [54]. This could also be the possible explanation of less decrease in $\mathrm{C}$ with the increase in depth in the subsoil, as clay protects SOM from decomposition by enhancing the spatial inaccessibility of SOM within soil aggregates as well as the interactions with mineral surfaces $[51,55]$.

\section{Total Organic Nitrogen (TON)}

The results of the effect of soil depths on TON content for the secondary forest, rubber, and oil palm plantation aged 5 and 15 years, are summarized in Table 1. As shown in Table 1 , the topsoil $(0-30 \mathrm{~cm}$ depth) has significantly higher TON content than the rest of the soil depths, i.e., $30-60$ and $60-90 \mathrm{~cm}$.
On the effect of land cover on the TON the $0-30 \mathrm{~cm}$ topsoil of the secondary forest was observed to have significantly greater TON content than the topsoils $(0-30 \mathrm{~cm})$ of the oil palm aged 5 and 15 years, as well as that in the rubber plantation. The effect of location on TON content was found to be significant in the secondary forest compared to the oil palm aged 5 and 15 years, and rubber plantation at the $60-90 \mathrm{~cm}$ depths. Furthermore, significant differences were observed between locations for the $30-60 \mathrm{~cm}$ depth, with the secondary forest displaying the greatest percentage of TON content in comparison with those of rubber and oil palm aged 5 and 15 years (Table 1).

Fig. 2 shows the effect of low nitrogen content on an oil palm plantation resulting in yellowing of the leaves. This is also supported by the lower nitrogen contents in the oil palm plantations aged 5 and 15 years in comparison with the secondary forest (Table 1).

The $0-30 \mathrm{~cm}$ had the greatest soil TON between depths, while the secondary forest had the greatest TON between locations. Previous studies have demonstrated that the soil TON in a secondary forest and at plantation sites significantly decreased down the soil profile [56]. In addition, this is consistent with the general observation that TON decreases with increasing soil depth because of a corresponding decrease in organic $\mathrm{N}$ down the profile. In general, the percentage of TON obtained in this study for the oil palm plantations aged 5 and 15 years, as well as the secondary forest, was within the range reported by $[13,57]$.

Furthermore, total nitrogen content in plantations were less than those in the secondary forest soil. However, this was inconsistent with the results demonstrated by [58-59], whose study found no significant differences between forest and plantations for TON. As our findings concurred with the results of the study by $[42,60]$, these authors averred the possible reason to the continuous fertilizer application that resulted in decreases in soil nutrient levels and cycling, e.g., nitrogen. Other possible reasons can be linked to the agricultural practices such as initial land clearance, water table management, and liming [58]. Moreover, $\mathrm{pH}$ increase under plantation might have increased the organic matter decomposition in soils,

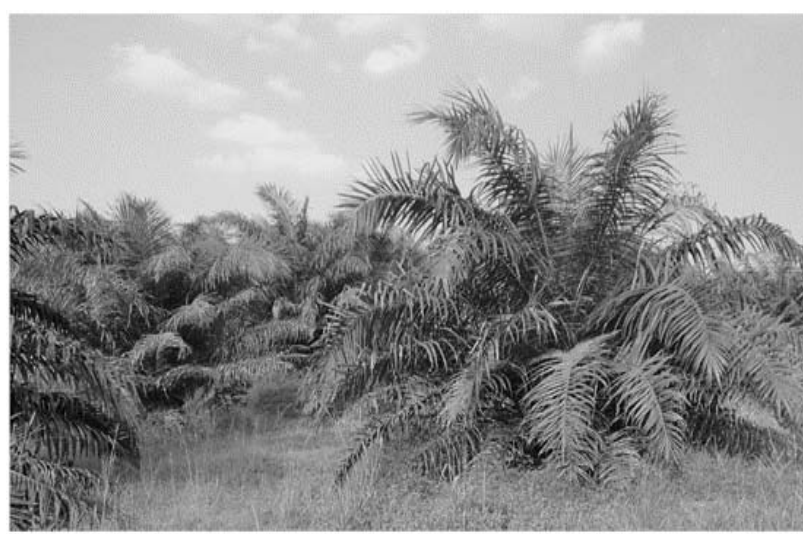

Fig. 2. Oil palm plantation at UPM. 
and hence promoted the mineralization processes and leaching, which results in the loss of soluble $\mathrm{N}$ from the soil system [52].

\section{$\mathrm{C} / \mathrm{N}$}

The findings on the effect of soil depths on $\mathrm{C}: \mathrm{N}$ ratios were observed to be similar between differences in depths and locations (Table 1). The highest $\mathrm{C} / \mathrm{N}$ ratio among depths was observed within 30-60 cm, while the oil palm aged 5 years exhibited the highest $\mathrm{C} / \mathrm{N}$ ratio among plantations. The $\mathrm{C} / \mathrm{N}$ ratios of the secondary forest and those of the plantation sites were stable with soil depth and slightly higher than in the secondary forest. In general, the conversion of forest to plantation do not alter the $\mathrm{C} / \mathrm{N}$ ratio. These results are consistent with those of the previous studies that demonstrated that forest conversion to various land cover showed no significant differences for the $\mathrm{C} / \mathrm{N}$ ratio $[51,58]$. Another explanation for the stable $\mathrm{C} / \mathrm{N}$ ratio values at all the sites is because nitrogen was found to be very low as an alternative to carbon.

\section{The Effects of Land Cover and Depth on $\left(\delta^{13}\right.$ Cand $\left.\delta^{15} N\right)$ Stable Isotopes}

\section{Stable Isotope $\left(\delta^{13} \mathrm{C}\right)$ Analysis}

The results of the effect of soil depths on $\delta{ }^{13} \mathrm{C}$ for the secondary forest, rubber, and oil palm plantation aged 5 and 15 years are summarized in Table 2, which shows that

Table 2. Comparison of $\delta^{13} \mathrm{C}(\%)$ and $\delta^{15} \mathrm{~N}(\%)$ of the secondary forest, rubber, and oil palm plantations aged 5 and 15 years between depths and land use.

\begin{tabular}{|c|c|c|c|}
\hline \multirow{2}{*}{$\begin{array}{c}\text { Land } \\
\text { use }\end{array}$} & \multicolumn{3}{|c|}{$\delta^{13} \mathrm{C}(\%)$} \\
\cline { 2 - 4 } & $0-30$ & $30-60$ & $60-90$ \\
\cline { 2 - 4 } SF & $-30.25 \pm 0.77 \mathrm{a} . \mathrm{A}$ & $-29.36 \pm 0.72$ & $-28.70 \pm 0.39$ \\
\hline $\mathrm{R}$ & $-27.01 \pm 0.20 \mathrm{~b} . \mathrm{B}$ & $-27.59 \pm 0.18$ & $-27.78 \pm 1.32$ \\
\hline OP5 & $-26.85 \pm 0.81 \mathrm{~b} . \mathrm{B}$ & $-27.72 \pm 0.19$ & $-27.09 \pm 0.77$ \\
\hline OP15 & $-28.82 \pm 0.29 \mathrm{ab} . \mathrm{AB}$ & $-28.34 \pm 0.65$ & $-27.44 \pm 0.74$ \\
\hline & \multicolumn{3}{|c|}{$\delta^{15} \mathrm{~N}(\%)$} \\
\hline SF & $-2.03 \pm 0.74 \mathrm{a}$ & $1.78 \pm 0.66 \mathrm{~b}$ & $4.21 \pm 0.29 \mathrm{~b} . \mathrm{A}$ \\
\hline $\mathrm{R}$ & $-4.47 \pm 0.73 \mathrm{a}$ & $2.11 \pm 0.58 \mathrm{~b}$ & $3.99 \pm 0.38 \mathrm{~b} . \mathrm{A}$ \\
\hline Op5 & $-3.75 \pm 0.72 \mathrm{a}$ & $1.54 \pm 0.44 \mathrm{~b}$ & $1.99 \pm 0.79 \mathrm{~b} . \mathrm{B}$ \\
\hline OP15 & $-3.18 \mathrm{a} \pm 0.55 \mathrm{a}$ & $2.54 \pm 0.38 \mathrm{~b}$ & $2.74 \pm 0.16 \mathrm{~b} . \mathrm{B}$ \\
\hline
\end{tabular}

$* \mathrm{SF}=$ secondary forest, $\mathrm{R}=$ rubber, $\mathrm{OP} 5=$ oil palm 5 years, OP15 $=$ oil palm 15 years

*Values are means \pm SE. Means followed by small letter (a-c) are significantly different for each parameters in raw (among depth); meanwhile, A-C means are significantly different for each parameter in columns (among land use) using least significant differences (LSD); $\mathrm{p} \leq 0.05$. No letter following indicates no significant differences. the topsoil, i.e., the $0-30 \mathrm{~cm}$ depth, had significantly lower $(\mathrm{p}<0.05) \delta{ }^{13} \mathrm{C}$ content of $-30.25 \%$ at the secondary forest relative to the $30-60 \mathrm{~cm}(-28.70 \%)$ and the $60-90 \mathrm{~cm}$ $(-29.36 \%)$ depths. Similarly, the oil palm aged 15 years had significantly lower $\delta{ }^{13} \mathrm{C}$ of -28.82 at the $0-30 \mathrm{~cm}$ depth relative to the 30-60 and 60-90 cm depths, respectively.

Fig. 3 demonstrated a close range of SOC under oil palm plantation aged 15 years relative to the secondary forest showing a consistent trend of $\delta^{13} \mathrm{C}$ at the same site, thereby indicating the importance of $\delta^{13} \mathrm{C}$ as an indicator of change in soil quality.

With respect to the effect of land cover on $\delta^{13} \mathrm{C}(\%)$, the oil palm plantation aged 5 years and the rubber had significantly greater $\delta^{13} \mathrm{C}(\%)$ content between locations for the $0-30 \mathrm{~cm}$ depths compared to those of the secondary forest and aged 15 years.

Concerning the depth of the profile, the $0-30 \mathrm{~cm}$ depth exhibited the greatest $\delta^{13} \mathrm{C}$, while with respect to location the oil palm aged 5 years exhibited the greatest $\delta^{13} \mathrm{C}$. This implied that the SOC was more intensively decomposed in the topsoil of the plantation. Additionally, fertilizer application has also been reported to influence the SOC and $\delta^{13} \mathrm{C}[18,61]$. According to [62] $\mathrm{NO}^{3-} \mathrm{N}$ sources cause an increase in soil $\mathrm{pH}$, which usually decreased $\mathrm{P}$ uptake by plants, which in turn leads to an increase in $\delta^{13} \mathrm{C}$ [63-64]. We can also see that the low range of SOC under oil palm plantation aged 15 years as compared to the secondary forest have a consistent trend for the $\delta^{13} \mathrm{C}$ in both sites. This indicates the significance of $\delta^{13} \mathrm{C}$ as an indicator of change in soil quality. Furthermore, studies have emphasized the fact that higher $\delta^{13} \mathrm{C}$ and $\delta^{15} \mathrm{~N}$ isotope enrichments in low-fertility soil classes coincide with depletion patterns of $\delta^{13} \mathrm{C}$ and $\delta^{15} \mathrm{~N}$ isotopes in highly fertile soil classes [65]. The $\delta^{13} \mathrm{C}$ values, however, showed similar patterns in the subsoil below $30 \mathrm{~cm}$, which is a good indicator of $\mathrm{C}$ loss from the plantation within the top soil. In general, the $\delta^{13} \mathrm{C}$ values recorded in this study were in line with the range of values reported by [51].

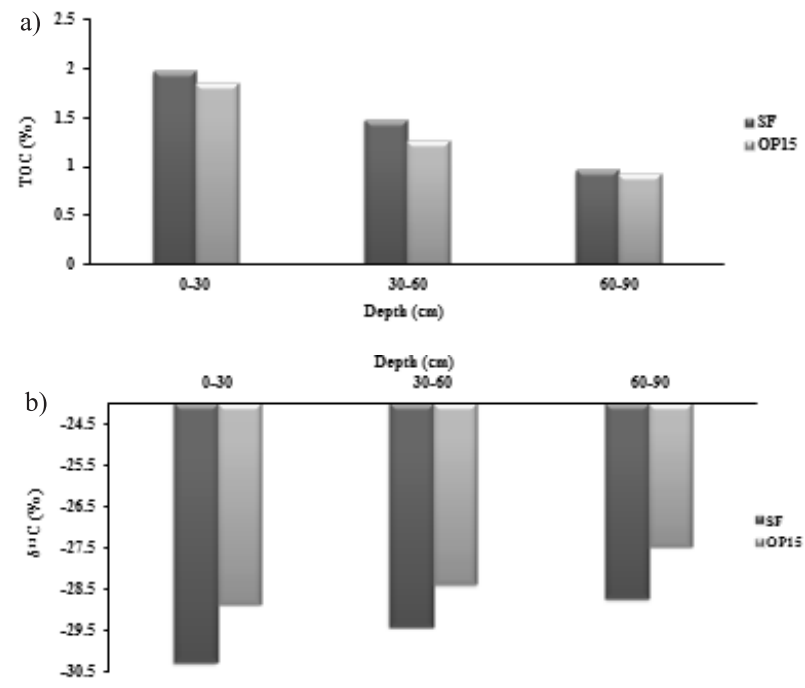

Fig. 3. Showing the effects of land uses conversion on the content of TOC $(\%)$ and $\delta^{13} \mathrm{C}$ in the soil. 
Table 3. Contribution of chemical parameters related to land use changes.

\begin{tabular}{|c|c|c|c|c|}
\hline \multirow{2}{*}{ Parameter } & \multicolumn{4}{|c|}{ Land use } \\
\cline { 2 - 5 } & SF & R & OP5 & OP15 \\
\hline $\mathrm{pH}$ & $3.13 \pm 0.03$ & $3.85 \pm 0.12$ & $3.40 \pm 0.25$ & $1.96 \pm 0.18$ \\
\hline SOC & $1.97 \pm 0.04$ & $1.30 \pm 0.01$ & $1.32 \pm 0.16$ & $0.14 \pm 0.01$ \\
\hline SON & $0.18 \pm 0.03$ & $0.09 \pm 0.01$ & $0.11 \pm 0.02$ & $3.21 \pm 0.22$ \\
\hline SOM & $3.39 \pm 0.06$ & $2.25 \pm 0.02$ & $2.29 \pm 0.28$ & 9.17 \\
\hline Total & 8.67 & 7.49 & 7.12 & $43.18 \%$ \\
\hline$P(\%)$ of $\mathrm{pH}$ & $36.10 \%$ & $51.40 \%$ & $47.75 \%$ & $20.28 \%$ \\
\hline$P(\%)$ of SOC & $22.72 \%$ & $17.35 \%$ & $18.53 \%$ & $1.52 \%$ \\
\hline$P(\%)$ of SON & $2.07 \%$ & $1.20 \%$ & $1.54 \%$ & $35.01 \%$ \\
\hline$P(\%)$ of SOM & $39.10 \%$ & $30.04 \%$ & $32.16 \%$ & $0.13 \%$ \\
\hline
\end{tabular}

*Note: means within a column between locations at $0-30 \mathrm{~cm}, \mathrm{SF}=$ secondary forest, $\mathrm{R}=$ rubber, $\mathrm{OP} 5=$ oil palm 5 years, $\mathrm{OP} 15=$ oil palm 15 years

$* P=$ contribution of each parameter

\section{Stable Isotope $\left(\delta^{15} \mathrm{~N}\right)$ Analysis}

Table 2 presents the results of the effect of soil depths on $\delta{ }^{15} \mathrm{~N}$ for the secondary forest, rubber, and oil palm plantation aged 5 and 15 years. As illustrated in Table 2, the subsoil (i.e., $60-90 \mathrm{~cm}$ depth) had significantly higher $\delta{ }^{15} \mathrm{~N}$ content than the $30-60$ and the $0-30 \mathrm{~cm}$ depths. The same trend was observed under the rubber and oil palm aged 5 and 15 years.

The results of the effect of land cover on $\delta^{15} \mathrm{~N}(\%)$ indicated that the secondary forest and the rubber had significantly greater $\delta^{15} \mathrm{~N}(\%)$ content between locations relative to the oil palm aged 5 and 15 , respectively, for the 60-90 cm depths.

While the $\delta^{15} \mathrm{~N}$ and the $60-90 \mathrm{~cm}$ depths had the highest $\delta^{15} \mathrm{~N}$, the secondary forest had the highest $\delta^{15} \mathrm{~N}$ between locations. Interestingly, in contrast to the generalized patterns of $\delta^{15} \mathrm{~N}$ displaying positive values in tropical soil, results of $\delta^{15} \mathrm{~N}$ obtained in this study exhibited negative values of $\delta^{15} \mathrm{~N}$ at the topsoil $(0-30 \mathrm{~cm})$ depths. The unusually negative values of $\delta^{15} \mathrm{~N}$ at the topsoil in this study indicated that $\mathrm{N}$ was a product of multiple variables such as $\mathrm{N}$ fixation, precipitation, rainstorm, and the use of chemical fertilizers. Several investigators had also demonstrated similar results, e.g., [66-68]. The authors mentioned above attributed this to atmospheric $\mathrm{N}_{2}$, which is usually the raw material for fertilizer production, and $\delta^{15} \mathrm{~N}$ values of $\mathrm{N}$ fertilizers are usually close to atmospheric $\mathrm{N}_{2}$, thereby resulting in increased precipitation as suggested by [69]. The depletion in the $\delta^{15} \mathrm{~N}$ could partially explain the low soil total $\mathrm{N}$ as suggested by $[25,70]$, and using phosphate fertilizer which causes reduction of the fractionating losses and increased microbial demand for $\mathrm{N}$ under $\mathrm{P}$ addition as suggestion by [71]. According to [72-73], N-deficient oil palm will have yellow leaves as shown previously in Fig. 2. Further, deficiency in oil palm can be due to $\mathrm{N}$ unavailability in soils. In contrast, when the soil depth profile was increased, the value of $\delta^{15} \mathrm{~N}$ became significantly higher. According to $[56,66,74-$ 75], $\delta{ }^{15} \mathrm{~N}$ increases with the age of SOM and the extent of decomposition. Within all the soil profiles, the increase in $\delta^{15} \mathrm{~N}$ was most marked in the $30-60 \mathrm{~cm}$ depth, and little change occurred in the $60-90 \mathrm{~cm}$ depth.

It is noteworthy that this increase in $\delta^{15} \mathrm{~N}$ with depth can be attributed to the movement of organic $\mathrm{N}$ down the soil profiles with time because this movement is also related to the greater clay content down the profiles.

The contribution of the chemical properties calculated for all the study locations is summarized in Table 3. The results show that $\mathrm{pH}$ was the most important factor

Table 4. Correlation between SOM, $\mathrm{pH}$, and $\delta^{15} \mathrm{~N}$ stable isotopes in different land use at $0-30 \mathrm{~cm}$.

\begin{tabular}{|c|c|c|c|c|}
\hline \multirow{2}{*}{ Land use } & & \multicolumn{3}{|c|}{ Treatment } \\
\cline { 3 - 5 } & & $\mathrm{pH}$ & $\delta^{15} \mathrm{~N}$ & SOM (\%) \\
\hline \multirow{4}{*}{$\mathrm{SF}$} & $\mathrm{pH}$ & 1 & & \\
\cline { 2 - 5 } & $\delta^{15} \mathrm{~N}$ & $0.924^{* *}$ & 1 & \\
\cline { 2 - 5 } & $\mathrm{SOM}(\%)$ & -0.997 & -0.848 & 1 \\
\hline \multirow{4}{*}{$\mathrm{R}$} & $\mathrm{pH}$ & 1 & & \\
\cline { 2 - 5 } & $\delta^{15} \mathrm{~N}$ & $0.910^{* *}$ & 1 & \\
\cline { 2 - 5 } & $\mathrm{SOM}(\%)$ & $-0.825^{* *}$ & $-0.908^{* *}$ & 1 \\
\hline \multirow{4}{*}{ OP5 } & $\mathrm{pH}$ & 1 & & \\
\cline { 2 - 5 } & $\delta^{15} \mathrm{~N}$ & $0.772^{*}$ & 1 & \\
\cline { 2 - 5 } & $\mathrm{SOM}(\%)$ & -0.600 & $-0.827^{* *}$ & 1 \\
\hline \multirow{3}{*}{ OP 15 } & $\mathrm{pH}$ & 1 & & \\
\cline { 2 - 5 } & $\delta^{15} \mathrm{~N}$ & $0.830^{* *}$ & 1 & \\
\cline { 2 - 5 } & $\mathrm{SOM}(\%)$ & $-0.959^{* *}$ & $-0.832^{* *}$ & 1 \\
\hline
\end{tabular}

**Correlation is significant at the 0.01 level (two-tailed),

*Correlation is significant at the 0.05 level (two-tailed) 
contributing to the chemical parameters affected by land use, followed by SOM.

\section{Relationship between Soil Organic Matter (SOM), $\mathrm{pH}$, and $\delta^{15} \mathrm{~N}$ Stable Isotope}

The results from the correlation analysis indicated that $\delta^{15} \mathrm{~N}$ had a strong positive correlation with $\mathrm{pH}$ and strong negative correlation with $\mathrm{SOM} \%$, while $\mathrm{pH}$ had a strong negative correlation with\% SOM as shown in Table 4.

Regarding the contribution of the physicochemical properties and correlation analysis, it was confirmed that $\mathrm{pH}$ influences decomposition rates of SOM, which increases the $\mathrm{pH}$ value [52]. In this study, $\mathrm{pH}$ was also found to be the most important factor affecting SOM decomposition and $\delta^{15} \mathrm{~N}$ distribution.

\section{Conclusions}

In conclusion, this study demonstrated that land-use change resulted in a significant change in soil chemical parameters - specifically in the topsoil. The conversion of secondary forest to oil palm plantation resulted in increased SOC and SON content over time, as indicated by the SOC and $\delta^{13} \mathrm{C}$ results. The $\delta^{15} \mathrm{~N}$ values revealed that $\mathrm{N}$ fixation, precipitation, and rainstorm were the most important sources of $\mathrm{N}$ in the topsoil. In addition, $\mathrm{pH}$ played a significant role in SOM decomposition and enrichment of $\delta^{15} \mathrm{~N}$ values with depth. Therefore, the results of this study have demonstrated that soil depth has no significant effect on soil organic matter enrichment in soils converted from secondary forest status to plantation status, contrary to previous studies that reported greater organic matter content with depth compared to soil surface.

\section{Acknowledgements}

This study was funded by the Ministry of Higher Education (MOHE), Malaysia through the Longterm Research Grant Scheme (LRGS) project No. LRGS/6375401. The first author wishes to thank the Universiti Putra Malaysia for support from a graduate research fellowship scholarship, and additional appreciation goes to the Libyan Embassy for their guidance. Special thanks to the laboratory assistants of the Faculty of Environmental Studies for lending a hand in the research, and the Taman Pertanian Universiti (TPU) Department for allowing me to collect the samples used in this research. We express our gratitude toward the research officer at Agency Nuclear Malaysia, Mr. Roslan Zairi Mostapa, for his assistance in isotope analysis.

\section{References}

1. SANDERMAN j., AMUNDSON R.G., BALDOCCHI D.D. Application of eddy covariance measurements to the temperature dependence of soil organic matter mean residence time. Global Biogeochem. CY. 17 (2), 2003.

2. PAUSTIAN K., LEHMANN J., OGLE S., REAY D., ROBERTSON G.P. Climate-smart soil. Nature, 532, 49, 2016.

3. WICK A.F., INGRAM L.J., STAHL P.D. Aggregate and organic matter dynamics in reclaimed soils as indicated by stable carbon isotopes. Soil Biol. Biochem. 41 (2), 201, 2009.

4. LLORENTE M., BELEN TURRIÓN M. Microbiological parameters as indicators of soil organic carbon dynamics in relation to different land use management. Eur. J. Forest Res. 129 (1), 73, 2010.

5. ROVIRA P., VALLEJO V.R. Physical protection and biochemical quality of organic matter in Mediterranean calcareous forest soils: a density fraction approach. Soil Biol. Biochem. 35 (2), 245, 2003.

6. VAN AARDENNE J.A., DENTENER F.J., OLIVIER J.G.J, KLEINGOLDEIJK C.G.M., LELIEVELD J.A. $1 \times 1$ resolution data set of historical anthropogenic trace gas emission for the period 1890-1990. Global Biogeochem. CY. 15 (4), 909, 2001.

7. HOUGHTON R.A. Why are estimates of the terrestrial carbon balance so different? Global Change Biol. 9 (4), 500, 2003.

8. VAN DER WERF G.R., MORTON D.C., DEFRIES R.S., OLIVER J.G.J., KASIBHATLA P.S., JACKSON R.B., COLLATZ G.J., RANDERSON J.T. $\mathrm{CO}_{2}$ emission from forest loss. Nature Geoscience, 2, 237, 2009.

9. TUBIELLO F.N. , SALVATORE M., FERRARA A.F., HOUSE J., FEDERICI S., ROSSI S., BIANCALANI R., CONDOR GOLEC R. D., JACOBS H., FLAMMINI A., PROSPERI P., CARDENAS-GALINDO P., SCHMIDHUBER J., SANZ SANCHEZ M,J., SRIVASTAVA N., SMITH P. The contribution of agriculture, forestry and other land use activities to global warming. Global Change, 21 (7), 2655, 2015.

10. OGLE S.M., BREDIT F,J., PAUSTAIN K. Agricultural management impacts on soil organic carbon storage under moist and dry climate conditions of temperate and tropical regions. Biogeochemistry, 72 (1), 87, 2005.

11. BUSCH J., FERRETTI-GALLON K., ENGELMANN J., WRIGHT M., AUSTIN K.G., STOLLE F., TURUBANOVA S., POTAPOV P.V., MARGONO B., HANSEN M.C., BACCINI A. Reductions in emissions from deforestation from Indonesia's moratorium on new oil palm, timber, and logging concessions. Proceeding of the National Academy of Science of the United State America, 112 (5), 1328, 2015.

12. KOTOWSKA M.M., LEUSCHNER C., TRIADIATI T., MERIEM S., HERTEL D. Quantifying above- and belowground biomass carbon loss with forest conversion in tropical lowlands of Sumatra (Indonesia). Global Change Biol. 21 (10), 3620, 2015.

13. FRÃZAO L.A., PAUSTIAN K., PELLEGRINO CERRI C.E., CERRI C.C. Soil carbon stocks and changes after oil palm introduction in the Brazilian Amazon. Global Biol. Bioen. 5 (4), 384, 2013.

14. FLYNN H.C., CANALS L. M., KELLER E., KING H., SIM S., HASTINGS A., WANG S. SMITH P. Quantifying global greenhouse gas emission from land-use change for crop production. Global Change Biol. 18 (5), 1622, 2012.

15. KHASANAH N., VAN NOORDWIJK M., NINGSIH H., RAHAYU S. Carbon neutral? No change in mineral soil carbon stock under oil palm plantations derived from forest or non-forest in Indonesia. Agr. Ecosyst. Environ. 211, 195, 2015. 
16. BOUTTON T.W., ARCHER S.R., MIDWOOD A.J., ZIZER S.F., BOL R. $\delta^{13} \mathrm{C}$ values of soil organic carbon and their use in documenting vegetation change in a subtropical savanna ecosystem. Geoderma, 82 (1), 5, 1998.

17. BERNOUX M., CERRI C.C., NEILL C., DE MORAES J.F.L. The use of stable carbon isotope for estimating soil organic matter turnover rates. Geoderma, 82 (1), 43, 1998.

18. BUSARI M., SALAKO F., TUNIZ C. Stable isotope technique in the elevation of tillage and fertilizer effects on soil carbon and nitrogen sequestration and water use efficiency. Eur. J. Agron. 73, 98, 2016.

19. DE ROUW A., SOULILEUTH B., HUON S. Stable carbon ratios in soil and vegetation shift with cultivation practices (North Laos). Agr. Ecosyst. Environ. 200, 161, 2015.

20. NATELHOFFER K.J., FRY B. Controls on natural nitrogen-15 and carbon -13 abundances in forest soil organic matter. Soil Sci. Soc. Am. J. 52 (6). 1633, 1988.

21. ZHANG K., DANG H., ZHANG Q., CHENG X. Soil carbon dynamics following land-use change varied with temperature and precipitation gradients: evidence from stable isotopes. Global Change Biol. 21 (7), 2762, 2015.

22. BALESDENT J., MARIOTTI A. Measurement of soil organic matter turnover using 13C natural abundance, pp. 83-111 in T W BOUTTON and S. I. YAMASAKA, editors. Mass spectrometry of soils. Marcel Dekker, New York, New York, USA. 1996.

23. ZHU X., CHEN H., ZHANG W., HUANG J., FU S., LIU Z., MO J. Effects of nitrogen addition on litter decomposition and nutrient release in two tropical plantations with N2fixing vs. non-N2-fixing tree species. Plant Soil, 399 (1), 61, 2016.

24. PICCOLO M.C., NEILL C., MELILLO J.M., CERRI C.C., STEUDLER P.A. $15 \mathrm{~N}$ natural abundance in forest and pasture soils in the Brazilian amazon Basin. Plant Soil, 182 (2), 249, 1996.

25. TANAKA-ODA A., KENZO T., INOUE Y., YANO M., KOBA K., ICHIE T. Variation in leaf and soil $\delta 15 \mathrm{~N}$ in diverse tree species in a lowland dipterocarp rainforest, Malaysia. Trees, 30 (2), 509, 2016.

26. SOMMER J., DIPPOLD M.A., FLESSA H., KUZYKOV Y. Allocation and dynamics of $\mathrm{C}$ and $\mathrm{N}$ within plant-soil system of ash and beech. J. Plant Nutr. Soil Sci. 179 (3), 376, 2016.

27. JOBBẢGY E.G., JACKSON R.B. The vertical distribution of soil organic carbon and its relation to climate and vegetation. Ecol. Appl. 10 (2), 423, 2000.

28. DAVIDSON E.A., JANSSENS I.A. Temperature sensitivity of soil carbon decomposition and feedbacks to climate change. Nature, 440, 165, 2006.

29. PERVEEN N., BAROT S., ALVAREZ G., KLUMOO K., MARTIN R. Priming effect and microbial diversity in ecosystem functioning and response to global change: a modelling approach using the SYMPHONY model. Global Change Biol. 20 (4), 1174, 2014.

30. PARAMANANTHAN S. Keys to the identification of Malaysian soils using parent martials, 2rd Edn Param Agricultural Soil Surveys (M) Sdn. BHD Malaysia, 2, 2012.

31. FAO-UNESCO Soil map of the world. Revised legend. World Resources Report 60. FAO, Rome.1988.

32. MILLER W., MILLER D. A micro-pipette method for soil mechanical analysis. Commun. Soil Sci. Plant Anal. 18 (1). 1987.

33. HEIRI O., LOTTER A.F., LEMCKE G. Loss on ignition as a method for estimating organic and carbonate content in sediments: reproducibility and comparability of results. J. Paleolimnol. 25 (1), 101, 2001.
34. ZULKIFLI S.Z., MOHAMAT-YUSUFF F., MUKHTAR A., ISMAIL A., MIYAZAK N. Determination of food web in intertidal mudflat of tropical mangrove ecosystem using stable isotope markers: A preliminary study. Life Sci. J.11 (3), 427, 2014.

35. SANAULLAH A.F.M., AKHTARUZZAMAN M., UDDIN M. Effect of Topography and Soil Depth on Clay Content, Organic Matter Content, Active Acidity, Reserve Acidity and Cation Exchange Capacity of Some Tea Soils of Bangladesh. J. Sci. Res. 8 (2), 229, 2016.

36. YAO M.K., ANGUI P.K.T., KONATÉ S., TONDOH J.E., TANO Y. Effects of land use types on soil organic carbon and nitrogen dynamics in Mid-West Cote d'Ivoire. Eur. J. Sci. Res. 40 (2), 211, 2010.

37. BATJES N. H., DIJKSHOORN J.A. Carbon and nitrogen stocks in the soils of the Amazon Region. Geoderma, 89 (3), 273, 1999.

38. KIZILKAYA R., DENGIZ O. Variation of land use and land cover effects on some soil physico-chemical characteristics and soil enzyme activity. Zemdirbyste-Agriculture, 97 (2), $15,2010$.

39. TANAKA S., TACHIBE S., WASLI M.E.B., LAT J., SEMAN L., KENDAWANG J. J., IWASAK K., SAKURAI K. Soil characteristics under cash crop farming in upland areas of Sarawak, Malaysia. Agr. Ecosyst. Environ. 129 (13), 293, 2009.

40. TWENEBOAH K.C. Modern Agriculture in the Tropics with Special Reference to West Africa. Cash Crops, CO-Wood Publishers, Accra- 278, 2000.

41. CH'NGHUCK Y., AHMED O.H., NIK MUHAMAD A.M., JALLOH M.B. Effects of converting secondary forest on peat to oil palm plantation on carbon sequestration. Am. J. Agr. Biol. Sci. 4 (2), 123, 2009.

42. ALLEN K., CORRE M.D., KURNIAWAN S., UTAMI S.R.,VELDKAMP E. Spatial variability surpasses land-use change effects on soil biochemical properties of converted lowland landscapes in Sumatra, Indonesia. Geoderma, 284, 42, 2016.

43. GANDASECA S., SALIMIN M.L., AHMED O.H. Effect of cultivation in different age's oil palm plantation on selected chemical properties of peat swamp soils. Agriculture, Forestry and Fisheries, 3 (6-1), 6, 2014.

44. STRAATEN O.V., CORRE M.D., WOLF K., TCHIENKOUA M., CUELLAR E., MATTHEWS R.B., VELDKAMP E. Conversion of lowland tropical forests to tree cash crop plantations loses up to one-half of stored soil organic carbon. Conversion of lowland tropical forests to tree cash crop plantations loses up to one-half of stored soil organic carbon. Nation. Acad. Sci., 112 (32), 9956, 2015.

45. COMTE I., COLIN F., GRUNBERGER O., FOLLIAN S., WHALEN J.K., CALIMAN P. Landscape-scale assessment of soil response to long-term organic and mineral fertilizer application in an industrial oil palm plantation, Indonesia. Agr. Ecosys. Environ. 169. 58, 2013.

46. AMUNDSON R. The carbon budget in soils. Ann. Rev. Earth and Pl. Sci. 29 (1), 535, 2001.

47. KURNIAWAN S., CORREM.D., MATSONA.L. Conversion of lowland forests to oil palm and rubber plantations impacts nutrient leaching losses and nutrient retention efficiency in highly weathered soils in Sumatra, Indonesia. 2016.

48. HARON K., BROOKES P.C., ANDERSON J.M., ZAKARIA Z.Z. Microbial biomass and soil organic matter dynamics in oil palm (Elaeis guineensis Jacq.) plantations, West Malaysia. Soil Biol. Biochem. 30 (5), 547, 1998.

49. SLAMET B., SURATI JAYA I.N., HENDRAYANTO., TARIGAN S.D. Impact of Land Cover Changes in Tropical 
Lowland Rainforest Transformation System to Soil Properties. IJSBAR, 22 (2), 316, 2015.

50. HASSAN M.N.A., JARAMILLO P., GRIFFIN W.M. Life cycle GHG emissions from Malaysian oil palm bioenergy development: The impact on transportation sector's energy security. Energ. Policy, 39 (5), 2615, 2011.

51. GUILLAUME T., DAMRIS M., KUZYAKOV Y. Losses of soil carbon by converting tropical forest to plantations: erosion and decomposition estimated by $\delta 13 \mathrm{C}$. Global Change Biolo. 21 (9), 3548, 2015.

52. GEORGE N., KILLUR R.R.B., CORNELIO D.L. Land use conversion and soil properties in a lowland tropical landscape of Papua New Guinea. Jurnal Manajement Hutan Tropika, 19 (1), 39, 2013.

53. COOK R.L., BINKLEY D., MENDES J.C.T., STAPE J.L. Soil carbon stocks and forest biomass following conversion of pasture to broadleaf and conifer plantations in southeastern Brazil. Forest Ecol. Manag. 324, 37, 2014.

54. POWERS J.S., CORRE M.D., TWINE T.E., VELDKAMP E. Geographic bias of field observations of soil carbon stocks with tropical land-use changes precludes spatial extrapolation. Natil. Acad. Sci. 108 (15), 3618, 2011.

55. GUNINA A., KUZYAKOV Y. Pathways of litter $\mathrm{C}$ by formation of aggregates and SOM density fractions: implications from $13 \mathrm{C}$ natural abundance. Soil Biol. Biochem. 71, 95, 2014.

56. ROUTH J., BIANCHI T.S., HUTCHINGS J. A., KUHRY P., RANJAN R. K. Organic carbon characteristics in Swedish forest soil trace post-depositional carbon dynamics. Eur. J. Soil Sci. 67 (4), 492, 2016.

57. ADACHI M., BEKKU Y.S., RASHIDAH W., OKUDA T., KOIZUMI H. Differences in soil respiration between different tropical ecosystems. Appl. Soil Ecol. 34 (2-3), 258, 2006.

58. GEISSEN V., SÄNCHEZ-HERNÄNDEZ R., KAMPICHLER C., RAMOS-REYES R., SEPULVEDALOZADA A., OCHOA-GOANA S., DE JONG B.H.J., HUERTA-LWANGA E., HERNANDEZ-DAUMAS S. Effects of land-use change on some properties of tropical soils-an example from Southeast Mexico. Geoderma, 151 (2), 87, 2009.

59. POWERS J.S. Changes in soil carbon and nitrogen after contrasting land-use transitions in Northeastern Costa Rica. Ecosystems, 7 (2), 134, 2004.

60. DAVIDSON E.A., DE CARVALHO C.J.R., FIGUEIRA A.M., ISHIDA F.Y., OMETTO J. P. H. B., NARDOTO G. B., SABA R. T., HAYASHI S. N., LEAL E. C., VIEIRA I. C. G., MARTINELLI L. A. Recuperation of nitrogen cycling in Amazonian forests following agricultural abandonment. Nature, 447, 995, 2007.

61. WILTS A.R., REICOSKY D.C., ALLMARAS R.R., CLAPP E.C. Long-term corn residue effects. Soil Sci. Soc. Am. J. 68 (4), 1342, 2004.

62. HAVLIN J.L., BEATON J.D., NELSON W.L., TISDALE S.L. Soil fertility and fertilizers: An introduction to nutrient management 515. Pearson Prentice Hall Upper Saddle River, NJ. 2005.
63. DESROCHERS A., VAN DEN DRIESSCHE R., THOMAS B.R. NPK fertilization at planting of three hybrid poplar clones in the boreal region of Alberta. Forest Ecol. Manag. 232 (1), 216, 2006.

64. DESROCHERS A., VAN DEN DRIESSCHE R., THOMAS B.R. The interaction between nitrogen source, soil $\mathrm{pH}$, and drought in the growth and physiology of three poplar clones This article is one of a selection of papers published in the Special Issue on Poplar Research in Canada. Botany, 85 (11), 1046, 2007

65. VITORELLO V.A., CERRI C.C., VICTÒRIA R.L., ANDREUX F., FELLER C. Organic matter and natural carbon-13 distribution in forested and cultivated oxisols. Am. J. Soil Sci. Soc. 53 (3), 773, 1989.

66. SZPAK P. Complexities of nitrogen isotope biogeochemistry in plant-soil systems: implications for the study of ancient agricultural and animal management practices. Front. Plant Sci. 5, 1, 2014.

67. YONEYAMA T., BOUTTON T., YAMASAKI S. Characterization of natural $15 \mathrm{~N}$ abundance of soils. Mass Spectrom. Soils. 1996.

68. CHOI W., RO H., HOBBIE E.A. Patterns of natural $15 \mathrm{~N}$ in soils and plants from chemically and organically fertilized uplands. Soil Biol. Biochem. 35(11), 1493, 2003.

69. SHEARER G., KOHL D.H., CHIEN S. The nitrogen-15 abundance in a wide variety of soils. Soil Sci. Soc. Am. J. $42(6), 899,1978$

70. CHEN R., HU J., DITTERT K., WANG J., ZHANG J., LIN $X$. Soil total nitrogen and natural 15 Nitrogen in response to long-term fertilizer management of a maize-wheat cropping system in Northern China. Commun. Soil Sci. Plant Anal. 42 (3), 322, 2011.

71. MAYOR J.R., WRIGHT S.J., SCHUUR E.A.G., BROOKS M.E., TURNER B.L. Stable nitrogen isotope patterns of trees and soils altered by long-term nitrogen and phosphorus addition to a lowland tropical rainforest. Biogeochemistry, 119 (1-3), 293, 2014.

72. BANABAS M. Study of Nitrogen Loss Pathways in Oil Palm (Elaeis Guineensis Jacq.) Growing Agro-ecosystems on Volcanic Ash Soils in Papua New Guinea: A Thesis Presented in Partial Fulfilment of the Requirements for the Degree of Doctor of Philosophy in Soil Science at Massey University, Palmerston North, New Zealand. 2007, Massey University, Palmerston North.

73. GOH K. J., HÄRDTER R., FAIRHURST T.H. The Oil PalmManagement for Large and Sustainable Yields (in press). In FAIRHURST, T.H and HARDTER R.,eds. Singapore: Potash \& Phosphate Institute of Canada. 2003.

74. NADELHOFFER K.J., FRY B. Nitrogen isotope studies in forest ecosystems.In: Lajtha K, Minchener RH (eds) Stable Isotopes in Ecology and Environmental Science. Boston, MA, USA: Blackwell Scientific Puplications. 23, 1994.

75. BRUNN M., CONDRON L., WELLS A., SPIELVOGEL S., OELMANN Y. Vertical distribution of carbon and nitrogen stable isotope ratios in topsoils across a temperate rainforest dune chronosequence in New Zealand. Biogeochemistry, 129 (1), 37, 2016. 